\title{
Association between home availability and vegetable consumption in youth: a review
}

\author{
Lauren T Cook ${ }^{1, *}$, Gillian A O'Reilly ${ }^{1}$, Christine J DeRosa ${ }^{2}$, Louise Ann Rohrbach ${ }^{1}$ and \\ Donna Spruijt-Metz ${ }^{1}$ \\ 'Department of Preventive Medicine, Keck School of Medicine, University of Southern California, 2250 Alcazar Street, \\ CSC-200, Los Angeles, CA 90089, USA: ${ }^{2}$ Los Angeles County Department of Public Health, Los Angeles, CA, USA
}

Submitted 2 July 2013: Final revision received 4 February 2014: Accepted 20 March 2014: First published online 1 May 2014

\begin{abstract}
Objective: To systematically review literature examining the association between vegetable home availability and vegetable intake in youth.

Design: Articles were identified through December 2012 using a search of PubMed, PsychINFO and OVID/Medline databases, using the following keywords in varying combinations: home, environment, availability, vegetable, intake, consumption, children. Quantitative studies examining home vegetable availability and vegetable intake in children and adolescents were included. Fifteen studies were included that met inclusion criteria.

Setting: Studies were conducted in the USA ( $n$ 8), Australia $(n 1)$, Greece $(n 1)$, Iceland ( $n$ 1), Denmark ( $n$ 1), the UK ( $n$ 1), the Netherlands $(n 1)$ and a combination of nine European countries $(n 1)$.

Subjects: Various populations of children and adolescents were examined.

Results: Seven of the studies ( $47 \%$ ) found a positive association between vegetable availability and intake, with the others reporting null findings. There were no clear patterns of association by study design, age of subjects included, comprehensiveness of measures, or inclusion of covariates in analyses. Child report of home availability was associated with child vegetable intake ( $n$ 6, all found a positive association), while parent report of home availability was only minimally associated ( $n$ ), one found a positive association; $P=0.001$ from post boc Fisher's exact test comparing parent $v$. child report).

Conclusions: Parent perception of availability may be closer to truth, given the parental role in food shopping and preparation. Therefore, to impact child vegetable intake, absolute availability may not be as important as child perception of vegetables in the home. Child perception of availability may be altered by level of familiarity with vegetables.
\end{abstract}

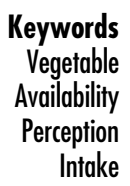

Advising increased intake of fruits and vegetables (F\&V) is a popular approach to combat child obesity. Consumption of F\&V is associated with decreased risk of chronic conditions like CVD and diabetes ${ }^{(1,2)}$, but intake patterns among children remain low, with just $1 \%$ of US adolescents meeting recommendations for $\mathrm{F} \& \mathrm{~V}$ intake ${ }^{(3)}$. Although F\&V are often considered together as one food category, there are distinct differences in determinants of fruit consumption $v$. vegetable consumption, such as barriers to consumption or knowledge of adequacy of intake $^{(4)}$. Also, the implications for disease risk differ between fruit consumption and vegetable consumption, with vegetable consumption having a stronger positive health impact compared with fruit consumption ${ }^{(5)}$. Given that intake of beneficial dark-green and orange vegetables is so low (median daily intake less than 0.06 cups in adolescents) ${ }^{(3)}$, factors that specifically impact child vegetable consumption should be examined.

A variety of influences impact child vegetable intake, including those at the individual level (such as preferences and self-efficacy) and those in the social and physical environment (including peer influence, parenting behaviour, neighbourhood availability and school lunch options) ${ }^{(6)}$. Home availability of vegetables, which is the presence of vegetables in the home, is a topic of interest because it may be both modifiable and important for improving child vegetable consumption. The presence of vegetables in the home may be modified by targeting behaviours ranging 
from those that are relatively simple, like increasing vegetable purchasing, to those that are more extensive, like growing a home garden. The objective of the present review paper is to examine the issue of importance: whether vegetable availability in the home is related to child vegetable consumption.

The relationship between home availability of vegetables and vegetable intake in children is presumed to act through two major pathways. The first pathway acts in the physical context, whereby foods that are present in the immediate environment are those from which meal and snack selections are made. The second pathway hinges on a child's perception of what foods are available. Certainly, perception of available foods is dependent on actual availability, but is also likely to be influenced by parent consumption of specific foods in the presence of the child, preparation of foods (e.g. when vegetables are prominently featured in meals) and child involvement in cooking and food shopping practices. In essence, familiarity with vegetables plays an important role in this pathway. Exposure, or the experience of tasting foods, has been extensively examined in experimental studies and is associated with child food preferences and intake ${ }^{(7,8)}$. Although exposure in a controlled experiment is not representative of habitual experience to foods in the home, the same underlying concept may influence preferences and intake, and may alter children's perceptions of what foods are available.

Other literature reviews have highlighted a positive association between home availability and $F \& V$ intake ${ }^{(9,10)}$, but to our knowledge the present one is the first to focus exclusively on the relationship between home availability and vegetable consumption. The present review examines this association in children based on studies utilizing varying measures and methodologies.

\section{Methods}

Articles published through December 2012 were collected using a search of PubMed, PsychINFO and OVID/Medline databases, using the following keywords in various combinations: home, environment, availability, vegetable, intake, consumption, children. Studies were included in the review if they met the following criteria: (i) presented data using a specific measure of vegetable (may include fruit) availability at home; (ii) presented data on child or adolescent vegetable intake (not combined with fruit or any other serving category); (iii) was peer-reviewed and quantitative; (iv) was conducted in a developed country; and (v) data presented were not an intervention outcome. Articles using samples from the developing world were excluded because determinants of vegetable consumption (and home availability) are likely very different in developed $v$. developing countries. Intervention outcomes were not included because programmes targeting home availability had other components (e.g. school-based nutrition education) ${ }^{(11)}$ that make it difficult to interpret how much change in consumption is attributable to the home environment.

Once articles were selected, they were evaluated for comprehensiveness of measures. Dietary measures that included a comprehensive recall or use of a survey containing at least five vegetable items were classified as highly comprehensive (e.g. this includes $24 \mathrm{~h}$ recalls or an extensive FFQ). Those with fewer than five vegetable survey items were classified as having low comprehensiveness. The cut-off point of five vegetable survey questions was chosen because the F\&V screener recommended by the National Cancer Institute contains five survey items on vegetable intake (not including potatoes and beans) ${ }^{(12)}$. A measure of this length allows for inclusion of different food types containing vegetables, thus creating a more robust indicator and minimizing recall bias. Similarly, measures that assessed the availability of at least five vegetables in the home were classified as highly comprehensive, and those that asked about fewer than five vegetables were classified as not comprehensive.

Studies were also classified on study design (crosssectional $v$. longitudinal), the age of children included, whether the study used parent or child report of home availability, and whether other social or physical aspects of the home environment (such as parenting behaviours) were included as covariates in the analyses. We did not classify the studies regarding use of parent $v$. child report of the child's dietary intake because although parent report would likely result in additional measurement error over typical dietary reporting error, only two studies included parent report of child dietary intake, and both of these were already classified as having a dietary measure with low comprehensiveness. A post hoc Fisher's exact test was used to compare outcome differences between studies that included parent $v$. child report of home availability of vegetables.

\section{Results}

As of December 2012, four hundred and fifty-four unique articles were retrieved. Figure 1 summarizes the reasons articles were excluded. A final sample of fifteen studies was included in the present review.

The majority of articles were excluded because they did not include measures of home availability and vegetable intake in children. Articles excluded also included two reports on a subset of participants from the Pro Children study $^{(13,14)}$. Brug et al. ${ }^{(15)}$ reported on this entire study sample and this article was included (details on measures from that study were described by Wind et al. ${ }^{(13)}$ ). Two additional studies that reported Pro Children data used unique measures, so these were also included in the present review ${ }^{(16,17)}$. One Pro Children study met inclusion criteria but was excluded because the article did not provide statistical significance values ${ }^{(18)}$. Two Pro Children longitudinal studies that reported data on 


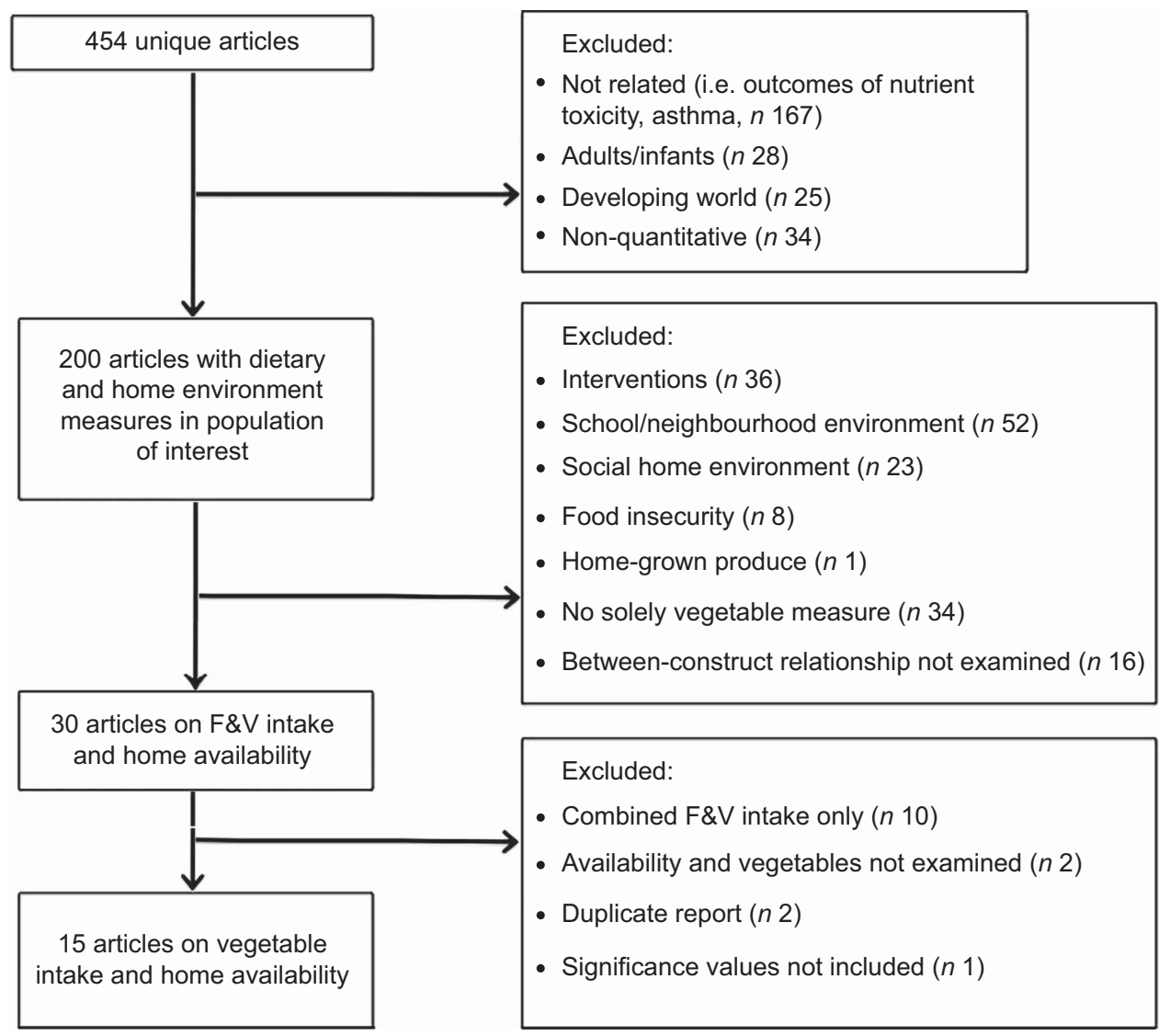

Fig. 1 Flowchart for articles included in the present review

adolescents and young adults combined were included in the present review, given that observation began in adolescence $^{(19,20)}$.

\section{Overview of study characteristics for included studies}

The sample characteristics (with potentially relevant demographics when reported), methods and findings of each article are briefly described in Table 1 . Of the fifteen included articles, one reported on children in Australia ${ }^{(21)}$, six reported on European children ${ }^{(15-17,22-24)}$ and eight reported on US youth ${ }^{(19,20,25-30)}$. Sample sizes ranged from ninety subjects ${ }^{(26)}$ to $13305^{(15)}$. Studies were conducted with children of various age groups, with one study targeting pre-schoolers ${ }^{(24)}$, six targeting children ${ }^{(15-17,22,23,25)}$ and eight targeting adolescents ${ }^{(19-21,26-30)}$.

Six studies reported the percentage of participants who were overweight/obese, ranging from $14 \%$ to $100 \%^{(22,23,25,27,29,30)}$, with one study by Gattshall et al. including only overweight children ${ }^{(25)}$. With the exception of a study by Lipsky et al. ${ }^{(29)}$, which was conducted with type 1 diabetics, all studies were conducted with healthy participants. Seven studies reported the ethnicity of their subjects, with non-Whites ranging from $24 \%$ to $100 \%$ of the sample ${ }^{(19,24-28,30)}$. Nine studies reported various measures of socio-economic status, including parent education or income, but no study samples were composed of only one sociodemographic group ${ }^{(20,22-28,30)}$.

Twelve studies included were cross-sectional ${ }^{(15-17,22-30)}$ and three were longitudinal ${ }^{(19-21)}$. A wide variety of measures was used in these studies, and Table 1 summarizes the comprehensiveness rating (high $v$. low) assigned to dietary and availability measures for each study. Dietary measures with low comprehensiveness included four studies with between one and three questions about vegetable intake $e^{(15,17,23,24)}$. All others had dietary measures with higher comprehensiveness, including $24 \mathrm{~h}$ recalls ${ }^{(17,26)}$, food records ${ }^{(29)}$, a six-item screener ${ }^{(28)}$ and FFQ with six to twenty-four vegetable items ${ }^{(19-22,25,27,30)}$. Nine studies had home availability measures composed of either one or two items, and were thus classified as having low comprehensiveness $^{(15-17,19-21,23,24,30)}$. Six studies had high comprehensiveness in the measure of home availability with scales of fifteen to twenty-six items ${ }^{(22,25-29)}$. All home availability measures were subjective, such that no home inventories or other direct measures were used in these studies, yet no studies used the term 'perceived' to refer to the availability measure. However, because direct measures of food availability, such as pantry inventories, may yield different results from the perceived measures used exclusively in the studies reported here, we refer to self-report measures as 'perceived'. 
Table 1 Summary of findings from articles included in the present review

\begin{tabular}{|c|c|c|c|c|c|c|c|}
\hline $\begin{array}{l}\text { Authors, year and } \\
\text { reference }\end{array}$ & $\begin{array}{l}\text { Sample size and descriptive } \\
\text { characteristics, study location, } \\
\text { study design* }\end{array}$ & Dietary measure & $\begin{array}{l}\text { Comprehensiveness } \\
\text { of dietary measure } \\
\text { (high/low) } \dagger\end{array}$ & Availability measure & $\begin{array}{l}\text { Comprehensiveness } \\
\text { of availability } \\
\text { measure (high/low) } \dagger\end{array}$ & $\begin{array}{l}\text { Source of report } \\
\text { on home } \\
\text { availability }\end{array}$ & $\begin{array}{l}\text { Findings (covariates } \\
\text { included) }\end{array}$ \\
\hline $\begin{array}{l}\text { Arcan et al. } \\
\qquad(2007)^{(19)}\end{array}$ & $\begin{array}{l}509 \text { adolescents ( } 37 \% \text { in middle } \\
\text { school, } 63 \% \text { in high school, } \\
73 \% \text { non-White, } 37 \% \text { low- or } \\
\text { middle/low-income) and } \\
\text { parents } \\
\text { USA } \\
\text { Longitudinal ( } 5 \text { years between } \\
\text { measures) } \ddagger\end{array}$ & $\begin{array}{l}\text { YAQ (FFQ including } \\
\text { nineteen vegetable } \\
\text { items) }\end{array}$ & High & One question F\&V & Low & Parent & $\begin{array}{l}\text { For temporality only: null } \\
\text { For change in intake: null } \\
\text { (demographic covariates, } \\
\text { adjusted for time } 1 \text { intake) }\end{array}$ \\
\hline $\begin{array}{l}\text { Befort et al. } \\
\quad(2006)^{(28)}\end{array}$ & $\begin{array}{l}198 \text { youth aged } 10-18 \text { years } \\
\text { ( } 73 \% \text { African American) and } \\
\text { parents } \\
\text { USA }\end{array}$ & $\begin{array}{l}\text { F\&V screener (six } \\
\text { vegetable items) }\end{array}$ & High & $\begin{array}{l}\text { Fifteen vegetable } \\
\text { item scale }\end{array}$ & High & Parent & $\begin{array}{l}\text { Null (demographic, personal } \\
\text { covariates; bivariate also } \\
\text { null) }\end{array}$ \\
\hline $\begin{array}{l}\text { Brug et al. } \\
\qquad(2008)^{(15)}\end{array}$ & $\begin{array}{l}13305 \text { children aged } 11 \text { years } \\
\text { Nine European countries }\end{array}$ & $\begin{array}{l}\mathrm{FFQ} \text { (three vegetable } \\
\text { items)§ }\end{array}$ & Low & $\begin{array}{l}\text { Two questions: one } \\
\text { fruit, one vegetable }\end{array}$ & Low & Child & $\begin{array}{l}\text { Positive }(\mathrm{OR}=1 \cdot 27,98 \% \mathrm{Cl} \\
1.12,1.44, \text { demographic } \\
\text { covariates) }\end{array}$ \\
\hline $\begin{array}{l}\text { Cutler et al. } \\
\qquad(2011)^{(30)}\end{array}$ & $\begin{array}{l}2516 \text { youth }(28 \% \text { in middle } \\
\text { school, } 72 \% \text { in high school, } \\
31 \% \text { overweight, } 46 \% \text { non- } \\
\text { White, } 15 \% \text { low income) } \\
\text { USA }\end{array}$ & $\begin{array}{l}\text { YAQ (FFQ including } \\
\text { nineteen vegetable } \\
\text { items) }\end{array}$ & High & $\begin{array}{l}\text { Four questions about } \\
\text { health home foods: } \\
\text { two } F \& V \text {, one juice, } \\
\text { one milk }\end{array}$ & Low & Child & $\begin{array}{l}\text { Positive }(\beta=0.02, P<0.01 \\
\quad \text { demographic covariates) }\end{array}$ \\
\hline $\begin{array}{l}\text { Edmonds et al. } \\
\qquad(2001)^{(26)}\end{array}$ & $\begin{array}{l}90 \text { African-American boys aged } \\
11-14 \text { years } \\
\text { USA }\end{array}$ & $2 \times 24 \mathrm{~h}$ recall & High & $\begin{array}{l}\text { Twenty-five F\&V and } \\
\text { juice item survey }\end{array}$ & High & Parent & $\begin{array}{l}\text { Null (demographic, } \\
\text { neighbourhood } \\
\text { environment covariates; } \\
\text { bivariate also null) }\end{array}$ \\
\hline $\begin{array}{l}\text { Gallaway et al. } \\
\quad(2007)^{(27)}\end{array}$ & $\begin{array}{l}473 \text { boys aged } 11-14 \text { years } \\
\text { ( } 27 \% \text { non-White, } 33 \% \\
\text { overweight/obese, } 70 \% \text { of } \\
\text { parents had college } \\
\text { education) } \\
\text { USA }\end{array}$ & $\begin{array}{l}\text { FFQ (twenty-four F\&V } \\
\text { and juice items) }\end{array}$ & High & $\begin{array}{l}\text { Forty-eight food item } \\
\text { scale }\end{array}$ & High & Child & $\begin{array}{l}\text { Positive }(\beta=0 \cdot 16, P<0 \cdot 01 \\
\text { demographic, personal } \\
\text { covariates) }\end{array}$ \\
\hline $\begin{array}{l}\text { Gattshall et al. } \\
\quad(2008)^{(25)}\end{array}$ & $\begin{array}{l}219 \text { overweight children aged } \\
8-12 \text { years ( } 87 \% \text { obese, } 37 \% \\
\text { non-White) and parents (63\% } \\
\text { with college education) } \\
\text { USA }\end{array}$ & $\begin{array}{l}\text { Block FFQ (six } \\
\text { vegetable items) }\end{array}$ & High & $\begin{array}{l}\text { Twenty-seven food } \\
\text { items survey }\end{array}$ & High & Parent & Positive $(r=0.22, P<0.01)$ \\
\hline $\begin{array}{l}\text { Koui and Jago } \\
(2008)^{(22)}\end{array}$ & $\begin{array}{l}167 \text { children in } 5 \text { th and } 6 \text { th } \\
\text { grades ( } 48 \% \text { overweight/ } \\
\text { obese) } \\
\text { Greece }\end{array}$ & $\begin{array}{l}\text { FFQ (sixteen } \\
\text { vegetable items) }\end{array}$ & High & $\begin{array}{l}\text { Sixteen vegetable } \\
\text { item survey }\end{array}$ & High & Child & $\begin{array}{l}\text { Positive ( } \beta=0.38, P<0 \cdot 01 \text {, } \\
\text { demographic covariates, } \\
\text { BMl; bivariate also } \\
\text { significant) }\end{array}$ \\
\hline
\end{tabular}




\begin{tabular}{|c|c|c|c|c|c|c|c|}
\hline $\begin{array}{l}\text { Authors, year and } \\
\text { reference }\end{array}$ & $\begin{array}{l}\text { Sample size and descriptive } \\
\text { characteristics, study location, } \\
\text { study design* }\end{array}$ & Dietary measure & $\begin{array}{c}\text { Comprehensiveness } \\
\text { of dietary measure } \\
\text { (high/low) } \dagger\end{array}$ & Availability measure & $\begin{array}{c}\text { Comprehensiveness } \\
\text { of availability } \\
\text { measure (high/low) } \dagger\end{array}$ & $\begin{array}{l}\text { Source of report } \\
\text { on home } \\
\text { availability }\end{array}$ & $\begin{array}{l}\text { Findings (covariates } \\
\text { included) }\end{array}$ \\
\hline $\begin{array}{l}\text { Kristjansdottir } \\
\text { et al. }(2009)^{(16)}\end{array}$ & $\begin{array}{l}963 \text { students in } 6 \text { th grade and } \\
\text { parents } \\
\text { Iceland§ }\end{array}$ & $\begin{array}{l}\mathrm{FFQ} \text { (three vegetable } \\
\text { items) }\end{array}$ & Low & $\begin{array}{l}\text { Two questions: one } \\
\text { fruit, one vegetable }\end{array}$ & Low & Parent & $\begin{array}{l}\text { Null (demographic, socio- } \\
\text { environmental, personal } \\
\text { covariates) }\end{array}$ \\
\hline $\begin{array}{l}\text { Krølner et al. } \\
\qquad(2009)^{(17)}\end{array}$ & $\begin{array}{l}1410 \text { students in } 5 \text { th grade } \\
\text { and parents } \\
\text { Denmark\| }\end{array}$ & $\begin{array}{l}24 \mathrm{~h} \text { recall } \\
\text { (dichotomized into } \\
\text { vegetable } \\
\text { consumers } v \text {. } \\
\text { non-consumers) }\end{array}$ & High & $\begin{array}{l}\text { Two questions: one } \\
\text { fruit, one vegetable } \\
\text { (dichotomous) }\end{array}$ & Low & Parent & $\begin{array}{l}\text { Null (demographic, social, } \\
\text { school environment } \\
\text { covariates) }\end{array}$ \\
\hline $\begin{array}{l}\text { Larson et al. } \\
\qquad(2008)^{(20)}\end{array}$ & $\begin{array}{l}1495 \text { adolescents (mean age } \\
15.9 \text { (SD 0.8) years) } \\
\text { USA } \\
\text { Longitudinal ( } 5 \text { years between } \\
\text { measures) } \ddagger\end{array}$ & $\begin{array}{l}\text { YAQ (FFQ including } \\
\text { nineteen vegetable } \\
\text { items) }\end{array}$ & High & Two questions F\&V & Low & Child & $\begin{array}{l}\text { For temporality only: positive } \\
(\beta=0.08-0.13, P<0.01, \\
\text { demographic covariates } \\
\text { and energy intake) } \\
\text { For change in intake: null } \\
\text { (further adjusting for } \\
\text { time } 1 \text { vegetable intake) }\end{array}$ \\
\hline $\begin{array}{l}\text { Lipsky et al. } \\
\qquad(2012)^{(29)}\end{array}$ & $\begin{array}{l}252 \text { adolescents with type } 1 \\
\text { diabetes (mean age } 13 \cdot 2 \\
\text { (sD } 2 \cdot 8 \text { ) years, } 34 \% \\
\text { overweight/ obese) and } \\
\text { parents } \\
\text { USA }\end{array}$ & $3 \mathrm{~d}$ food records & High & $\begin{array}{l}\text { Twenty-six vegetable } \\
\text { item scale }\end{array}$ & High & Parent & $\begin{array}{l}\text { Null (demographic } \\
\text { covariates) }\end{array}$ \\
\hline $\begin{array}{l}\text { McGowan et al. } \\
(2012)^{(24)}\end{array}$ & $\begin{array}{l}434 \text { parents of pre-school } \\
\text { children ( } 24 \% \text { non-White, } \\
64 \% \text { with university } \\
\text { education) } \\
\text { UK }\end{array}$ & $\begin{array}{l}\text { One question typical } \\
\text { intake }\end{array}$ & Low & $\begin{array}{l}\text { One question } \\
\text { currently } \\
\text { vegetables at } \\
\text { home }\end{array}$ & Low & Parent & $\begin{array}{l}\text { Null (demographic } \\
\text { covariates; bivariate } \\
\text { analysis was significant) }\end{array}$ \\
\hline $\begin{array}{l}\text { Pearson et al. } \\
(2011)^{(21)}\end{array}$ & $\begin{array}{l}1850 \text { adolescents aged } \\
12-15 \text { years } \\
\text { Australia } \\
\text { Longitudinal ( } 2 \text { years between } \\
\text { measures) }\end{array}$ & $\begin{array}{l}\text { FFQ (one vegetable } \\
\text { item) }\end{array}$ & Low & Two questions F\&V & Low & Child & $\begin{array}{l}\text { For change in intake: positive } \\
(\beta=0.03-0.04, P<0.05, \\
\text { demographic, personal } \\
\text { and socio-environmental } \\
\text { covariates, baseline } \\
\text { vegetable intake) }\end{array}$ \\
\hline $\begin{array}{l}\text { Reinaerts et al. } \\
\qquad(2007)^{(23)}\end{array}$ & $\begin{array}{l}1739 \text { parents of children aged } \\
4-12 \text { years }(14 \% \text { children } \\
\text { overweight/obese, } 27 \% \text { of } \\
\text { parents low educational level) } \\
\text { Netherlands }\end{array}$ & $\begin{array}{l}\text { Three questions } \\
\text { vegetable } \\
\text { frequency }\end{array}$ & Low & $\begin{array}{l}\text { Two questions always } \\
\text { F\&V at home and } \\
\text { having F\&V child } \\
\text { likes }\end{array}$ & Low & Parent & $\begin{array}{l}\text { Null (demographic, personal, } \\
\text { social covariates; bivariate } \\
\text { analysis was significant) }\end{array}$ \\
\hline
\end{tabular}


Table 2 Association between measure comprehensiveness and reported outcome

\begin{tabular}{llr}
\hline & \multicolumn{2}{c}{ Availability comprehensiveness } \\
\cline { 2 - 3 } Dietary rigour & \multicolumn{1}{c}{ High } & \multicolumn{1}{c}{ Low } \\
\hline High & $50 \%$ found positive association $(n 6)$ & $50 \%$ found positive association $(n 4)$ \\
Low & - & $40 \%$ found positive association $(n 5)$ \\
\hline
\end{tabular}

Table 3 Association between parent $v$. child report of availability and reported outcome

\begin{tabular}{ll}
\hline Parent report of availability & Child report of availability \\
\hline $11 \%$ found positive association $(n 9)$ & $100 \%$ found positive association $(n 6)^{*}$ \\
\hline
\end{tabular}

*Fisher's exact test $P=0.001$ comparing outcome ratios with parent $v$. child report.

\section{Summary of study findings}

Of the fifteen studies, seven (47\%) found a positive association between perceived home availability and vegetable consumption ${ }^{(15,20-22,25,27,30)}$. One article reported on pre-school children, and no association was found between availability and intake ${ }^{(24)}$. Six studies reported on children aged 4-12 years, and 50\% of these studies found a positive association ${ }^{(15,22,25)}$, with the others finding no relationship ${ }^{(16,17,23)}$. Eight studies reported on adolescents aged 10-18 years, and 50\% of these studies found a positive association ${ }^{(20,21,27,30)}$, with the others presenting null results ${ }^{(19,26,28,29)}$

Of the twelve studies with a cross-sectional design, five ( $42 \%$ ) reported a positive association between perceived home availability and consumption ${ }^{(15,22,25,27,30)}$ and seven reported no association ${ }^{(16,17,23,24,26,28,29)}$. Of the three studies that were longitudinal, two reported a positive association between home availability and vegetable intake $^{(20,21)}$ (one of which was positive when the temporal relationship only was examined, i.e. previous availability predicting later intake; but this was null for change in vegetable intake, i.e. once adjusted for baseline intake ${ }^{(20)}$ ). The final longitudinal study reported no association longitudinally or only temporally ${ }^{(19)}$. The remaining true longitudinal study reporting a positive association had a very small effect size $(\beta<0.05)$, as did one cross-sectional study $^{(21,30)}$. All longitudinal studies were conducted with adolescents.

\section{Comprebensiveness of measures}

A summary of the research findings by comprehensiveness classifications is presented in Table 2. Six studies had measures of dietary intake and perceived home availability that were both high in comprehensiveness ${ }^{(22,25-29)}$, and $50 \%$ of these studies reported a positive association between perceived home availability and child vegetable intake $^{(22,25,27)}$. Four studies had a highly comprehensive measure of dietary intake, but a measure of perceived home vegetable availability with low comprehensiveness ${ }^{(17,19,20,30)}$, and $50 \%$ of these found a positive relationship ${ }^{(20,30)}$. Two of these studies were longitudinal ${ }^{(19,20)}$, and one found a positive relationship for temporality only (null for change in vegetable intake $)^{(20)}$. Finally, five studies had measures of vegetable intake and perceived home availability that were both low in comprehensiveness ${ }^{(15,16,21,23,24)}$, and two (40\%) found a positive association ${ }^{(15,21)}$. One of these studies was longitudinal, and this study found a positive association ${ }^{(21)}$.

\section{Parent v. child report}

A summary of findings by parent $v$. child report of perceived home vegetable availability is presented in Table 3. Nine articles utilized parent report of perceived home vegetable availability. Eight of these studies found no association with

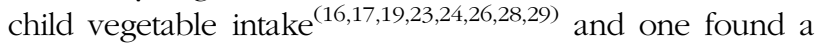
positive association $^{(25)}$. Six articles included child report of perceived home availability and all six found a positive association with child vegetable intake ${ }^{(15,20,21,22,27,30)}$. A Fisher's exact test to compare the ratio of positive $v$. null findings in parent $v$. child report of vegetable availability resulted in a $P$ value of 0.001 , suggesting that child perception of availability was more likely to be associated with intake than was parent perception of availability.

\section{Inclusion of covariates in analyses}

One study included only a bivariate analysis of perceived home availability and child vegetable consumption, and found a positive association between measures ${ }^{(25)}$. Six other studies also included a bivariate analysis of availability with intake (in addition to adjusted models) ${ }^{(19,22-24,26,28)}$, and 50\% of these bivariate outcomes had positive associations ${ }^{(22,24,25)}$. Ten studies reported analyses of the relationship between availability and vegetable consumption adjusting for demographic variables. Half of these studies found a positive association when controlling for demographics ${ }^{(15,20-22,30)}$ and half had null findings ${ }^{(16,19,24,26,29)}$. Six studies included both demographics and other predictor variables (such as food preferences, parenting behaviour and school food availability) in analyses. Two of these studies (33\%) found a positive association between availability and intake $\mathrm{e}^{(21,27)}$ and four $(67 \%)$ found no relationship ${ }^{(16,17,23,28)}$. 


\section{Discussion}

Approximately half of the studies examining the association between home vegetable availability and child vegetable intake found a positive relationship, with the other studies finding null results. Few studies used comprehensive measures of availability and intake, yet even among the studies that assessed both constructs with the use of comprehensive measures, results were inconsistent. Similarly, there was no consistent pattern of positive $v$. null results in studies with cross-sectional $v$. longitudinal designs, within any age group, or when analyses controlled for different covariates. The lack of consistent findings among studies that included comprehensive measures or adjustments for covariates makes it difficult to draw conclusions about the true underlying relationship between home availability of vegetables and children's consumption of them. In addition, it is likely that publication bias is minimal for this topic given that home availability was frequently one of many home environment measures reported (parenting practices were often included as a research question). A significant association between intake and another hypothesized determinant would make null findings for home availability with intake more likely to be published.

The one instance where results were generally consistent among studies was in parent $v$. child report of availability, with child report of perceived availability being significantly more likely to be associated with children's vegetable consumption compared with parent report. This is consistent with findings from a study on combined F\&V intake among a sample of seventy-three parent-child dyads that demonstrated that children's perceptions of the home food environment were more predictive of $\mathrm{F} \& \mathrm{~V}$ intake than parents' perceptions ${ }^{(31)}$. Also, the study by Kristjansdottir et al. included both parent and child report of home vegetable availability, although the findings from child report were not included in the present review because analysis was done on a sub-sample of that from the Brug et al. article ${ }^{(15,16)}$. In the Kristjansdottir et al. sample of 963 6th grade child-parent dyads, child perception of home vegetable availability was associated with child vegetable intake, whereas parent report was not ${ }^{(16)}$.

Notably, none of the studies in the present review included a home inventory of vegetables. Consequently, all measures were subjective, indicating that the term 'availability' actually refers to perceived availability. However, parent report can be assumed to be closer to the truth because parents often do the grocery shopping and cooking for their families. Therefore, these data suggest that perception of home vegetable availability by children may be an even more important predictor of vegetable intake than actual availability. Perceived availability may be determined by familiarity with certain foods, and this pathway is likely influenced by parental practices and the degree of child involvement in eating-related behaviours. There is some evidence for a causal relationship between familiarity and intake. For example, in an exposure-based experimental intervention with forty-nine children by Wardle et al., those given a vegetable and asked to try it every day for eight days demonstrated significant increases in both preferences and consumption of vegetables ${ }^{(32)}$. To our knowledge, an association between food familiarity or exposure and child report of home availability has not been documented.

Based on these findings, it may be helpful for interventions to target home availability of vegetables, especially when they involve children. Interventions have been shown to improve availability, and one study with 4th and 5th grade families reported that a nutrition and media intervention targeting the home environment improved home availability and accessibility of $F \& V^{(11)}$. Additionally, a community gardening programme with 4 th-6th graders that included a weekly family newsletter showed improvements in home vegetable availability ${ }^{(33)}$. Similarly, frequency of eating home-grown produce was associated with home availability and preferences for $\mathrm{F} \& \mathrm{~V}$ in pre-schoolers, as reported by a study with 1658 parents living in a rural setting ${ }^{(34)}$. Other topics for interventions could include more prominent vegetable storage and inclusion in meals, or involving children in vegetable preparation when cooking at home. Research is needed to determine if these strategies can be effective to increase vegetable intake.

Further research with rigorous study designs and comprehensive, objective measures (i.e. kitchen and pantry inventories) is also warranted, given that the majority of studies identified in the literature were cross-sectional and with substantial measurement limitations. Use of objective measures in conjunction with subjective measures that further examine the discrepancy between parent and child report will help elucidate the true relationship between availability and intake. However, for further studies examining child perception of $F \& V$ availability, a more comprehensive measure may not be necessary, which could reduce participant burden and may make comparisons easier between varying subject populations. Furthermore, to date only one study examining the relationship between availability and vegetable intake in pre-schoolers has been published. This may be a particularly important age group to focus on in the future, given that food preferences of pre-school children are maintained into early adulthood ${ }^{(35)}$.

Limitations of the present review should also be noted. The dichotomization cut-off point for measure comprehensiveness is not grounded in theory or evidence; however, alternative approaches are likely to have minimal impact on general conclusions. Similarly, there was not a clear distinction between child $v$. adolescent age groupings other than what was reported in the original manuscripts. Also, causality is difficult to interpret due to lack of consistency in longitudinal findings. When available from longitudinal studies, results on previous availability predicting later intake (rather than predicting change in intake) are used in comparison to cross-sectional studies ${ }^{(19,20)}$. However, one 
longitudinal study only reported the effect on change in vegetable intake, which is not directly comparable to studies examining intake at one point in time ${ }^{(21)}$. It may not be expected for vegetable intake to change if home availability also does not, although that study found a statistically significant association. However, this specific study and one other report significant findings with regression coefficients $<0 \cdot 1^{(21,30)}$, which may be considered by some to be a null relationship ${ }^{(36)}$. Also, the use of covariates varied widely, and adjusted results were used to summarize findings when available (direct comparisons between studies using unadjusted results, or assumptions about the role of covariates, would not be appropriate given the heterogeneity between study populations).

The present review has found that home availability of vegetables is most consistently associated with child intake when reported by children but not when reported by parents. Given that most children do not meet recommendations for vegetable intake, increasing exposure to vegetables in the home may be a valuable and relatively simple modification that families can make to improve child health.

\section{Acknowledgements}

Financial support: This research received no specific grant from any funding agency in the public, commercial or not-for-profit sectors. Conflict of interest: None. Authorship: L.T.C. developed the research question, conducted the literature review and drafted the manuscript. G.A.O., C.J.D., L.R. and D.S.-M. provided guidance throughout and gave feedback on the manuscript. Ethics of buman subject participation: Ethical approval was not required for this review.

\section{References}

1. Hung HC, Joshipura KJ, Jiang R et al. (2004) Fruit and vegetable intake and risk of major chronic disease. $J$ Natl Cancer Inst 96, 1577-1584.

2. Cooper AJ, Forouhi NG, Ye Z et al. (2012) Fruit and vegetable intake and type 2 diabetes: EPIC-InterAct prospective study and meta-analysis. Eur J Clin Nutr 66, 1082-1092.

3. Kimmons J, Gillespie C, Seymour J et al. (2009) Fruit and vegetable intake among adolescents and adults in the United States: percentage meeting individualized recommendations. Medscape J Med 11, 26.

4. Glasson C, Chapman K \& James E (2011) Fruit and vegetables should be targeted separately in health promotion programmes: differences in consumption levels, barriers, knowledge and stages of readiness for change. Public Health Nutr 14, 694-701.

5. Cooper AJ, Sharp SJ, Lentjes MA et al. (2012) A prospective study of the association between quantity and variety of fruit and vegetable intake and incident type 2 diabetes. Diabetes Care 35, 1293-1300.

6. McClain AD, Chappuis C, Nguyen-Rodriguez ST et al. (2009) Psychosocial correlates of eating behavior in children and adolescents: a review. Int J Behav Nutr Phys Act 6, 54.
7. Cooke L (2007) The importance of exposure for healthy eating in childhood: a review. J Hum Nutr Diet 20, 294-301.

8. Anzman-Frasca S, Savage JS, Marini ME et al. (2012) Repeated exposure and associative conditioning promote preschool children's liking of vegetables. Appetite $\mathbf{5 8}$, 543-553.

9. Jago R, Baranowski T \& Baranowski JC (2007) Fruit and vegetable availability: a micro environmental mediating variable? Public Health Nutr 10, 681-689.

10. Pearson N, Biddle SJ \& Gorely T (2009) Family correlates of fruit and vegetable consumption in children and adolescents: a systematic review. Public Health Nutr 12, 267-283.

11. Evans AE, Dave J, Tanner A et al. (2006) Changing the home nutrition environment: effects of a nutrition and media literacy pilot intervention. Fam Community Health 29, 43-54.

12. Thompson FE, Subar AF, Smith AF et al. (2002) Fruit and vegetable assessment: performance of 2 new short instruments and a food frequency questionnaire. J Am Diet Assoc 102, 1764-1772.

13. Wind M, de Bourdeaudhuij I, te Velde SJ et al. (2006) Correlates of fruit and vegetable consumption among 11-year-old Belgian-Flemish and Dutch schoolchildren. J Nutr Educ Behav 38, 211-221.

14. Kristjansdottir AG, Thorsdottir I, De Bourdeaudhuij I et al. (2006) Determinants of fruit and vegetable intake among 11-year-old schoolchildren in a country of traditionally low fruit and vegetable consumption. Int J Behav Nutr Phys Act 3, 41.

15. Brug J, Tak NI, te Velde SJ et al. (2008) Taste preferences, liking and other factors related to fruit and vegetable intakes among schoolchildren: results from observational studies. Br J Nutr 99, Suppl. 1, S7-S14.

16. Kristjansdottir AG, De Bourdeaudhuij I, Klepp KI et al. (2009) Children's and parents' perceptions of the determinants of children's fruit and vegetable intake in a low-intake population. Public Health Nutr 12, 1224-1233.

17. Krølner R, Due P, Rasmussen M et al. (2009) Does school environment affect 11-year-olds' fruit and vegetable intake in Denmark? Soc Sci Med 68, 1416-1424.

18. De Bourdeaudhuij I, Yngve A, te Velde SJ et al. (2006) Personal, social and environmental correlates of vegetable intake in normal weight and overweight 9 to 13-year old boys. Int J Behav Nutr Phys Act 3, 37.

19. Arcan C, Neumark-Sztainer D, Hannan P et al. (2007) Parental eating behaviours, home food environment and adolescent intakes of fruits, vegetables and dairy foods: longitudinal findings from Project EAT. Public Health Nutr 10, $1257-1265$.

20. Larson NI, Neumark-Sztainer DR, Harnack LJ et al. (2008) Fruit and vegetable intake correlates during the transition to young adulthood. Am J Prev Med 35, 33-37.

21. Pearson N, Ball K \& Crawford D (2011) Predictors of changes in adolescents' consumption of fruits, vegetables and energy-dense snacks. Br J Nutr 105, 795-803.

22. Koui E \& Jago R (2008) Associations between self-reported fruit and vegetable consumption and home availability of fruit and vegetables among Greek primary-school children. Public Health Nutr 11, 1142-1148.

23. Reinaerts E, de Nooijer J, Candel M et al. (2007) Explaining school children's fruit and vegetable consumption: the contributions of availability, accessibility, exposure, parental consumption and habit in addition to psychosocial factors. Appetite 48, 248-258.

24. McGowan L, Croker H, Wardle J et al. (2012) Environmental and individual determinants of core and non-core food and drink intake in preschool-aged children in the United Kingdom. Eur J Clin Nutr 66, 322-328.

25. Gattshall ML, Shoup JA, Marshall JA et al. (2008) Validation of a survey instrument to assess home environments for physical activity and healthy eating in overweight children. Int J Behav Nutr Phys Act 5, 3. 
26. Edmonds J, Baranowski T, Baranowski J et al. (2001) Ecological and socioeconomic correlates of fruit, juice, and vegetable consumption among African-American boys. Prev Med 32, 476-481.

27. Gallaway MS, Jago R, Baranowski T et al. (2007) Psychosocial and demographic predictors of fruit, juice and vegetable consumption among 11-14-year-old Boy Scouts. Public Health Nutr 10, 1508-1514.

28. Befort C, Kaur H, Nollen N et al. (2006) Fruit, vegetable, and fat intake among non-Hispanic black and non-Hispanic white adolescents: associations with home availability and food consumption settings. J Am Diet Assoc 106, 367-373.

29. Lipsky LM, Nansel TR, Haynie DL et al. (2012) Associations of food preferences and household food availability with dietary intake and quality in youth with type 1 diabetes. Appetite 59, 218-223.

30. Cutler GJ, Flood A, Hannan P et al. (2011) Multiple sociodemographic and socioenvironmental characteristics are correlated with major patterns of dietary intake in adolescents. J Am Diet Assoc 111, 230-240.
31. Robinson-O'Brien R, Neumark-Sztainer D, Hannan PJ et al. (2009) Fruits and vegetables at home: child and parent perceptions. J Nutr Educ Behav 41, 360-364.

32. Wardle J, Herrera ML, Cooke L et al. (2003) Modifying children's food preferences: the effects of exposure and reward on acceptance of an unfamiliar vegetable. Eur J Clin Nutr 57, 341-348.

33. Heim S, Bauer KW, Stang J et al. (2011) Can a communitybased intervention improve the home food environment? Parental perspectives of the influence of the delicious and nutritious garden. J Nutr Educ Behav 43, 130-134.

34. Nanney MS, Johnson S, Elliott M et al. (2007) Frequency of eating homegrown produce is associated with higher intake among parents and their preschool-aged children in rural Missouri. J Am Diet Assoc 107, 577-584.

35. Nicklaus S, Boggio V, Chabanet C et al. (2004) A prospective study of food preferences in childhood. Food Qual Prefer 15, 805-818.

36. Nunnally JC (1978) Psychometric Theory. New York: McGraw-Hill. 